\title{
PENGGUNAAN METODE DEMONSTRASI UNTUK MENINGKATKAN PRESTASI BELAJAR PESERTA DIDIK SEKOLAH DASAR NEGERI \\ LIMO 2 DEPOK KELAS VI PADA MATA PELAJARAN ILMU PENGETAHUAN ALAM DENGAN TEMA RANGKAIAN LISTRIK SEDERHANA SWERI DAN PARALEL
}

\author{
Inah ${ }^{1}$ \\ Guru SDN LIMO 2 Depok \\ surel: inah1277@gmail.com \\ Wahyu Bagja Sulfemi ${ }^{2}$ \\ STKIP Muhammadiyah Bogor \\ surel:wahyubagja@gmail.com
}

\begin{abstract}
ABSTRAK
Penelitian Tindakan Kelas ini dilakukan di Kelas VI SDN Limo 2 Depok padamata pelajaran IPA. Kelas yang diteliti adalah kelas VI yang berjumlah 38 orang peserta didik. Penelitian dilakukan tanggal 11, 18, 25 Januari 2018. Tujuan penelitian adalah untuk meningkatkan Prestasi Belajar belajar peserta didik kelas VI Sekolah Dasar Negeri Limo 2 pada mata pelajaran IPA dengan tema Rangkaian Listrik melalui metode demontrasi. Pada prasiklus diperoleh data nilai rerata 61 terdapat 20 atau (53\%) peserta didik tuntas. Pada siklus I didapat hasil nilai rerata 69 atau terdapat 28 (74\%) peserta didik tuntas dengan hasil pengamatan peserta didik yang dapat menjawab pertanyaan guru dengan benar sebanyak 21 (55,26\%). siklus 2 didapat data hasil nila rerata 81 . terdapat 34 peserta didik atau (89\%) tuntas, sedangkan hasil pengamatan didapat peserta didik yang dapat menjawab pertanyaan guru dengan benar sebanyak 27 (71,05\%). Dengan demikian penerapan metode demonstrasi telah memberikan pengaruh yang sangat baik dengan termotivasi peserta didik untuk belajar, materi yang disampaikan guru dimengerti, peserta didik memiliki tanggung jawab terhadap tugasnya, dan peserta didik terlibat aktif di dalam kelas Hal berdampak meningkatnya prestasi belajar peserta didik. yang belajar peserta didik mata pelajaran IPA di kelas VI SDN Limo 2 Depok.
\end{abstract}

Kata Kunci : Prestasi Belajar, IPA, metode demonstrasi

\section{PENDAHULUAN}

\section{A. Latar Belakang Masalah}

Pendidikan Ilmu Pengetahuan Alam (IPA) merupakan pendidikan bidang studi dengan alam semesta serta segala proses yang terjadi di 
dalamnya sebagai objeknya. Oleh karena perkembangan ilmu pengetahuan alam erat kaitannya dengan perkembangan teknologi, maka pendidikan ilmu pengetahuan alam berkaitan pula dengan perkembangan teknologi serta manfaatnya bagi masyarakat. Melalui pendidikan ilmu pengetahuan alam diharapkan peserta didik memahami proses dan produk sains, nilai sains memiliki sikap ilmiah dan dapat menjadi warga Negara yang bermoral serta tanggap terhadap masalah lingkunganya.

Setelah peneliti melaksanakan tes prasiklus pada peserta didik kelas VI Sekolah Dasar Negeri (SDN) Limo 2 Mata pelajaran Ilmu Pengetahuan Alam (IPA) dengan tema Rangkaian Listrik melalui diperoleh data hasil rerata peserta didik hanya 61 dari KKM 70 yang ditetapkan. Sehingga terdapat 18 peserta didik (47\%) mendapat nilai di bawah KKM, 12 peserta didik (32\%) mendapat nilai sama dengan KKM dan hanya 8 peserta didik (21\%) yang mendapat nilai di atas KKM. Sedangkan melalui hasil pengamatan, peserta didik yang dapat menjawab pertanyaan guru $36,84 \%$ dan yang belum dapat menjawab sebesar $63,16 \%$.

Rendahnya Prestasi belajar tersebut disebabkan beberapa faktor dan kondisi di lingkungan belajar, baik dari faktor peserta didik, sarana serta prasarana, maupun dari kompetensi guru itu sendiri, dalam menyajikan metode yang lebih berfariasi dalam proses pembelajaran. Sehingga kemampuan guru di tuntut dalam mengelola kelas agar suasana belajar siswa selalu aktif dan produktif dengan metode mengajar yang direncanakan. Selain itu guru harus memiliki pemahaman yang baik mengenai materi ke-IPA-an, metode pembelajaran, dan sistem penilaian, serta tujuan-tujuan pembelajaran IPA.

Melihat kenyataan tersebut peneliti merasa tertarik untuk melakukan penelitian Tindakan Kelas dengan tujuan meningkatkan "Meningkatkan Prestasi Belajar Peserta Didik Kelas VI SDN Limo 2 Depok pada Mata Pelajaran IPA dengan Tema Rangkaian Listrik Sederhana Sweri dan Paralel Melalui Metode Demonstrasi”. 


\section{KAJIAN PUSTAKA}

\section{A. Prestasi Belajar}

Prestasi belajar adalah sebuah kalimat yang terdiri dari dua kata, yakni "prestasi" dan "belajar", mempunyai arti yang berbeda. Untuk memahami lebih jauh tentang pengertian prestasi belajar, peneliti menjabarkan makna dari kedua kata tersebut.

Dalam Kamus Besar Bahasa Indonesia (2008 : 787) yang dimaksud dengan prestasi adalah "hasil yang telah dicapai (dilakukan, dikerjakan dan sebagainya)." Lebih lanjut prestasi adalah suatu kegiatan yang telah dikerjakan, diciptakan baik secara individual atau kelompok Masih dalam Kamus Besar Bahasa Indonesia (2008 : 1101) pengertian prestasi adalah hasil yang telah dicapai atau dilakukan dikerjakan. Sedang Prestasi belajar belajar adalah berusaha memperoleh kepandaian atau ilmu "penguasaan pengetahuan atau keterampilan yang dikembangkan oleh mata pelajaran, lazimnya ditunjukkan dengan nilai tes atau angka nilai yang diberikan oleh guru."

Menurut Slameto (2003 : 2) bahwa belajar ialah "Suatu usaha yang dilakukan seseorang untuk memperoleh suatu perubahan tingkah laku yang baru secara keseluruhan, sebagai hasil pengalamannya sendiri dalam interaksi dengan lingkungannya. Muhibbinsyah (2004 : 136) menambahkan dalam bukunya Psikologi Belajar bahwa belajar adalah "tahapan perubahan seluruh tingkah laku individu yang relatif menetap sebagai hasil pengalaman dan interaksi dengan lingkungan yang melibatkan proses kognitif".

Menurut Insight, dalam Anitah (2009 :2.16) belajar adalah mengubah pemahaman peserta didik. Menurut teori ini peserta didik merupakan individu yang utuh. Belajar selalu diarahkan untuk mengembangkan kemampuan tingkat tinggi dan juga berpikir tinggi. Lebih lanjut Gestalt, dalam Anitah (2009 :2.16) belajar dapat pula dikatakan sebagai suatu proses, artinya dalam

proses belajar akan terjadi suatu proses intelektual, fisik, dan mental guna mengubah perilaku peserta didik yang dapat diwujudkan dalam proses 
aktivitas melihat, membuat, mengamati, menyelesaikan masalah dan menyimak

Sementara itu menurut Gagne (1985) dalam Anitah (2009:1.3) belajar adalah suatu proses dimana suatu organisme berubah perilakunya sebagai akibat pengalaman. Dari pengertian tersebut terdapat 3 ciri utama yaitu proses, perubahan perilaku atau tingkah laku, dan pengalaman. Selanjutnya menurut Ernest R. Hilgard dalam Anitah (2009 : 2.4), belajar merupakan proses perubahan tingkah laku yang diperoleh melalui latihan. Perubahan ini di sebabkan oleh adanya dukungan dari lingkungan yang positif yang menyebabkan terjadinya interaksi edukatif.

Menurut Kamus Besar Bahasa Indonesia (2008 : 1101) pengertian prestasi belajar belajar adalah berusaha memperoleh kepandaian atau ilmu "penguasaan pengetahuan atau keterampilan yang dikembangkan oleh mata pelajaran, lazimnya ditunjukkan dengan nilai tes atau angka nilai yang diberikan oleh guru." Begitu juga menurut James O. Whitaker yang dikutip oleh Soemanto (2005 : 98-99) dalam bukunya Psikologi Pendidikan, memberikan definisi bahwa belajar adalah "proses dimana tingkah laku ditimbulkan atau diubah melalui latihan dan pengalaman".

Dalam hal ini prestasi belajar merupakan suatu kemajuan dalam perkembangan siswa setelah ia mengikuti kegiatan belajar dalam waktu tertentu. Seluruh pengetahuan, keterampilan, kecakapan dan perilaku individu terbentuk dan berkembang melalui proses belajar.

Faktor-faktor yang mempengaruhi prestasi belajar dibedakan menjadi tiga macam, yaitu :

1) Faktor Internal (faktor dari dalam diri siswa), yakni keadaan/kondisi jasmani atau rohani siswa

2) Faktor Eksternal (faktor dari luar siswa), yakni kondisi lingkungan sekitar siswa

3) Faktor Pendekatan Belajar (approach to learning), yakni jenis upaya belajar siswa yang meliputi strategi dan metode yang digunakan siswa untuk melakukan kegiatan pembelajaran materi-materi pelajaran. (Syah, 
$2000: 139)$

Jadi prestasi belajar adalah hasil yang dicapai oleh siswa selama berlangsungnya proses belajar mengajar dalam jangka waktu tertentu, umumnya prestasi belajar dalam sekolah berbentuk pemberian nilai (angka) dari guru kepada siswa sebagai indikasi sejauhmana siswa telah menguasai materi pelajaran yang disampaikannya, biasanya prestasi belajar ini dinyatakan dengan angka, huruf, atau kalimat dan terdapat dalam periode tertentu. Oleh karena itu kita sebagai seorang guru harus dapat memperhatikan peserta didik secara seksama agar perilaku yang diinginkan dapat tercapai secara optimal oleh peserta didik. Hal ini sangat erat kaitannya dengan evaluasi pembelajaran yang diberikan guru kepada peserta didiknya. Prosedur evaluasi pembelajaran harus sesuai dengan prosedur pembelajaran sehingga dapat menilai proses dan hasil belajarnya.

\section{B. Hakikat Ilmu Pengetahuan Alam}

Pembelajaran IPA menurut Tim Penyusun Naskah PLPG PGSD FIP UNJ (2011:195) IPA adalah suatu objek atau bidang studi yang membahas kenyataan, fakta-fakta, dan teori-teori untuk menggambarkan tentang kerja dari alam dan merupakan kreasi dari pemikiran manusia dalam mengemukakan ide-idenya ataupun konsep-konsep secara bebas.

Menurut Sapriati (2012:2.3) Pendidikan IPA di sekolah dasar bertujuan agar siswa menguasai pengetahuan, fakta, konsep, prinsip, proses penemuan, serta memiliki sikap ilmiah, yang akan bermanfaat bagi siswa dalam mempelajari diri dan alam sekitar. Filosofi IPA sebagai cara untuk mencari tahu yang berdasarkan pada observasi.

Dengan demikian, pengetahuan dalam IPA merupakan hasil observasi yang disimpulkan berdasarkan hasil observasi. Kebenaran harus dibuktikan secara empiris berdasarkan observasi atau eksperimen. Pengembangan pembelajaran IPA yang menarik, menyenangkan, layak, sesuai konteks, serta didukung oleh ketersediaan waktu, keahlian, sarana dan prasarana merupakan kegiatan yang tidak mudah untuk dilaksanakan. Seorang guru dituntut 
memiliki kemampuan dan kreatifitas yang cukup agar pembelajaran dapat terselenggarakan secara efektif dan efisien. Salah satu aspek kemampuan yang harus dimiliki sorang guru adalah tentang pemahaman dan penguasaan terhadap pendekatan pembelajaran.

Menurut Piaget dalam Sapriati (2012:1.19) ada sedikitnya tiga hal yang perlu diperhatikan dalam merancang pembelajaran di kelas, terutama dalam pembelajaran IPA. Ketiga hal tersebut adalah:

1. Seluruh anak melewati tahapan yang sama secara berurutan.

2. Anak mempunyai tanggapan yang berbeda terhadap suatu benda atau kejadian.

3. Apabila hanya kegiatan fisik yang diberikan kepada anak, tidaklah cukup untuk menjamin perkembangan intelektual anak.

Dengan demikian, pengetahuan dalam IPA merupakan hasil observasi yang disimpulkan berdasarkan hasil observasi. Kebenaran harus dibuktikan secara empiris berdasarkan observasi atau eksperimen. Pengembangan pembelajaran IPA yang menarik, menyenangkan, layak, sesuai konteks, serta didukung oleh ketersediaan waktu, keahlian, sarana dan prasarana merupakan kegiatan yang tidak mudah untuk dilaksanakan. Seorang guru dituntut memiliki kemampuan dan kreatifitas yang cukup agar pembelajaran dapat terselenggarakan secara efektif dan efisien. Salah satu aspek kemampuan yang harus dimiliki sorang guru adalah tentang pemahaman dan penguasaan terhadap pendekatan pembelajaran.

Berdasarkan penjelasan tersebut jelaslah bahwa mata pelajara ilmu pengetahuan alam merupakan pendidikan yang bertujuan untuk membentuk peserta didik memiliki sikap ilmiah dan dapat menjadi warga Negara yang bermoral serta tanggap terhadap masalah lingkunganya

\section{Metode Eksperimen}

Menurut Sagala (2005 : 220) metode eksperimen adalah cara penyajian bahan pelajaran dimana siswa melakukan percobaan dengan mengalami untuk membuktikan sendiri sesuatu pertanyaan atau hipotesis 
yang dipelajari. Metode eksperimen adalah suatu cara mengajar, di mana siswa melakukan suatu percobaan tentang sesuatu hal, mengamati prosesnya serta menuliskan hasil percobaannya, kemudian hasil pengamatan itu disampaikan ke kelas dan dievaluasi oleh guru

Metode eksperimen dapat dikembangkan keterampilan-keterampilan seperti: keterampilan mengamati, menghitung, mengukur, membuat pola, membuat hipotesis, merencanakan eksperimen, mengendalikan variable, mengintrespresikan data, membuat kesimpulan sementara, meramal, menerapkan , mengkomunikasikan dan mengajukan pertanyaan (Azhar: 2004 :45).

Kelebihan dari metode Eksperimen (1) peserta didik aktif mengalami atau membuktikan sendiri. (2) peserta didik dapat membuktikan sendiri teoriteori yang pernah diterima. (3) peserta didik mendapat kesempatan melakukan langkah-langkah berfikir ilmiah. Sedangkan Kelemahan Metode Eksperimen adalah (1). akan kurang berhasil apabila alat-alat dan bahan yang tersedia tidak mencukupi kebutuhan peserta didik. (2) kemungkinan tidak akan membawa hasil yang diharapkan apabila peserta didik belum cukup pengalaman. (3). kadang-kadang ada eksperimen yang waktunya panjang, sehingga waktu yang ada dijadwal pelajaran disekolah tidak cukup

Proses pembelajaran IPA dengan menggunakan metode eksperimen dapat meningkatkan keterampilan proses. Selain itu meningkatkan hasil belajar siswa. Berdasarkan uraian di atas disimpulkan bahwa, Ilmu Pengetahuan Alam dapat berkembang pesat berkat metode ilmiah. Proses pembelajaran IPA menurut keterlibatan siswa secara aktif dalam proses pembelajaran. Dengan metode eksperimen dalam proses pembelajaran dapat melatih siswa mengembangkan keterampilan intelektualnya. Diharapkan metode eksperimen dalam proses pembelajaran IPA akan dapat meningkatkan presentasi belajar dan semangat belajar secara aktif pada siswa

Dapat disimpulkan bahwa metode eksperimen merupakan metode yang dapat memberikan kesempatan kepada siswa untuk berlatih menemukan sendiri jawaban terhadap suatu masalah, atau membuktikan sendiri suatu 
proses dan hasil percobaan setelah melakukan serangkaian kegiatan percobaan

\section{Penelitian Tindakan Kelas (PTK)}

Menurut Wardani (2014:1.4) Penelitian Tindakan Kelas adalah penelitian yang dilakukan oleg guru di dalam kelasnya sendirimelalui refleksi diri dengan tujuan untuk memperbaiki kinerja sebagai guru sehingga hasil belajar siswa menjadi meningkat.

Selanjutnya menurut Arikunto (2012:3) mengemukakan Penelitian Tindakan Kelasmerupakan suatu pencermatan terhadap kegiatan belajar berupa sebuah tindakan yang sengaja dimunculkan dan terjadi dalam sebuah kelas yang bersamaan. Kemudian menurut Mohammad Asrori (2009:6) Penelitian Tindakan Kelas didefinisikan sebagai suatu bentuk yang bersifat reflektif dengan sehngga dapat hasil belajar yang lebih baik.

Tindakan Kelas adalah penelitian yang dilakukan didalam kelas oleh seorang guru dengan tujuan untuk memperbaiki proses pembelajaran dan meningkatkan hasil belajar siswa. Menurut Arikunto (2012:17) mengemukakan secara garis besar ada 4 tahap langkah-langkah penelitian kelas yaitu :

1. Menyusun Rencana Tindakan (planning)

2. Pelaksanaan Tindakan (action)

3. Pengamatan (observing)

4. Refleksi (reflecting)

Menurut Asrori (2009:61) menjelaskan langkah-langkah Penelitian Tindakan Kelas sebagai berikut :

1. Melakukan identifikasi masalah.

2. Melakukan analisa masalah dan perumusan masalah.

3. Merumuskan hipotesis tindakan sebagai alternative pemecahan masalah.

4. Analisis kelayakan pemecahan masalah. 
Menurut Supardi (2012 : 108) mengemukakan bahwa manfaat Penelitian Tindakan Kelas dapat dilihat dan dikaji dalam beberapa komponen pendidikan dan pembelajaran di kelas, diantaranya :

1. Inovasi pembelajaran.

2. Pengembangan kurikulum.

3. Peningkatan profesionalisme pendidikan.

Dari beberapa pengertian di atas dapat disimpulkan bahwa penelitian melakukan tindakan-tindakan tertentu untuk memperbaiki dan meningkatkan praktik pembelajaran di kelas secara lebih berkualitas

\section{PELAKSANAAN PENELITIAN PERBAIKAN PEMBELAJARAN}

\section{A. Subjek, Tempat, Waktu Penelitian dan Pihak yang Membantu}

\section{Subjek dan Tempat Penelitian}

Subjek penelitian adalah peserta didik kelas 1 yang berjumlah 31 Peserta didik terdiri dari sebagai 12 Laki- laki dan 19 Perempuan pada mata pelajaran IPS tentang "Peristiwa Penting yang di Alami" Tempat penelitian ini dilakukan di SDN Harjamukti 2 di jalan Pringgondani RT 03 RW 09 Kelurahan Harjamukti Kecamatan Cimanggis Kota Depok.

\section{Waktu Penelitian}

Penelitian ini dilaksanakan mulai hari Kamis tanggal, 14 Januari 2018 diawali dengan prasiklus yang menjadi sumber masalah yang ditemukan, kemudian dilanjutkan perbaikan pembelajaran siklus I pada hari Selasa tanggal, 19 Januari 2018. Selanjutnya perbaikan pembelajaran siklus 2 pada hari Kamis, tanggal 21 Januari 2018. Berikut tabel penelitian secara lengkap

\section{Pihak yang Membantu Penelitian}

1. Nentih S.Pd. sebagai supervisor 2

2. Tuti Suparyanti, M.Pd. selaku Kepala Sekolah SD Negeri Harjamukti 2. 


\section{B. Desain Prosedur Perbaikan Pembelajaran}

Dalam Penelitian ini dilaksanakan dua siklus yang masing-masing melalui 4 tahapan yaitu tahap perencanaan, pelaksanaan, pengamatan dan refleksi. Adapun pelaksanaan penelitian tersebut dideskripsikan sebagai berikut:

\section{Siklus 1}

\section{a. Persiapan}

1. Perencanaan pelaksanaan pembelajaran yang akan dilaksanakan pada hari, Selasa, tanggal 19 Januari 201814.

2. Guru menyusunan Rencana Pembelajaran IPS dengan Tema Peristiwa Penting yang di Alami

3. Penyusunan metode pembelajaran berupa ceramah dan tanya jawab.

4. Persiapan sumber belajar dan bahan ajar.

5. Penyusunan alat evaluasi pembelajaran atau lembar kerja peserta didik (LKS)

\section{b. Pelaksanaan}

1) Kegiatan awal (10 menit)

a) Guru mengajak peserta didik berdoa, mengisi daftar kelas, menulis hari dan tanggal di papan tulis dan mempersiapkan materi ajar.

b) Guru memperingatkan peserta didik cara duduk yang baik ketika menulis, membaca dan meluruskan barisan meja dan kursi mereka

c) Guru memberikan motivasi belajar kepada para peserta didik melalui "tepuk semangat" dan menyanyikan Pada Hari Minggu"

d) Guru memperlihatkan contoh peristiwa penting yang pernah dialami diikuti tanya jawab untuk mengetahui kemampuan awal peserta didik tentang apa yang akan dipelajari 
e) Guru menyampaikan tujuan pembelajaran setelah pembelajaran peserta didik dapat menyebutkan peristiwa yang pernah di alami

f) Guru menyampaikan topik yang akan dipelajari yaitu "Peristiwa Penting yang di Alami"

g) Guru mengaitkan tofik dengan menyampaikan manfaat konsep tersebut dalam kehidupan sehari-hari

2) Kegiatan inti (40 menit)

a) Guru menyebutkan beberapa Peristiwa Penting yang di Alami

b) Guru meminta peserta didik memperhatikan gambar Peristiwa Penting yang di Alami

c) Guru menjelaskan kejadian yang telah terjadi peristiwa ada yang penting ada yang biasa saja ada yang masih kita ingat ada pula yang sudah kita lupa.

d) Peserta didik dimita menyebutkan dan Peristiwa penting yang alami di rumah dan di lingkungan sekitar atau sekolah

e) Guru meminta beberapa peserta didik untuk maju kedepan menyebutkan peristiwa penting yang alami di rumah dan di lingkungan sekitar atau sekolah

f) Guru memberikan kesempatan peserta didik untuk bertanya

3). Kegiatan Akhir (20 menit)

a) Guru bersama peserta didik menyimpulkan pembelajaran

b) Guru memberikan tugas berupa LKS terkait materi yang baru saja dipelajari.

c) Peserta didik mengerjakan tugas yang diberikan guru.

d) Guru memberian PR / tugas

e) Menutup pelajaran

\section{c. Pengamatan}

Berdasarkan pengamatan dan observasi saat guru mengajar, yang menjadi permasalahan dalam pembelajaran tersebut adalah: 
a) Peserta didik kurang termotivasi dalam pembelajaran.

b) Nilai rata-rata kelas yang diperoleh 67,58 masih dibawah KKM yaitu 70,00, dan peserta didik yang dapat menjawab pertanyaan hanya 15 dari 31 peserta didik.

c) Tanggung jawab peserta didik akan tugas masih rendah, saat diberikan tugas belum dilaksanakan dengan optimal.

d) Media yang digunakan dalam pembelajaran belum maksimal

e) Keterlibatan peserta didik dalam kegiatan pembelajaran masih kurang.

\section{d. Refleksi}

Dari pelaksanaan pembelajaran siklus I, ditemukan kekuatan dan kelemahan dalam tindakan perbaikan pembelajaran diantaranya:

\section{Kekuatan}
a) Pembelajaran lebih efektif dengan metode .
b) Guru sudah melibatkan peserta didik dalam pembelajaran
c) Peserta didik mulai antusias terhadap media yang digunakan
d) Pemahaman materi oleh peserta didik sedikit lebih baik.

\section{Kelemahan}

a) Guru kurang memandu siswa

b) Aktiftas peserta didik belum semua terlibat

c) Belum semua peserta didik melakukan mengerti dengan tugasnya

d) Ruang kelas kurang kondusif karena masih ada anak yang sibuk dengan mengobrol.

e) Pembelajarn masih didominasi peserta didik yang aktif saja.

f) Perolehan hasil rata-rata kelas masih dibawah KKM yaitu diperoleh 67,58 masih dibawah KKM yaitu 70,00, dan peserta didik yang dapat menjawab pertanyaan hanya 15 dari 31 peserta didik. sehingga perlu dilanjutkan ke siklus berikutnya yaitu siklus II. 


\section{Siklus 2}

\section{a. Persiapan}

1) Perencanaan pelaksanaan pembelajaran yang akan dilaksanakan pada hari Kamis, tanggal 21 Januari 2018

2) Pada pertemuan sebelumnya guru menugaskan peserta didik untuk membawa foto keluarga, foto copi akte kelahiran, piagam, mainan waktu kecil, dan rapor Taman Kanak-Kanak

3) Guru menyusunan Rencana Pembelajaran IPS dengan Tema Peristiwa Penting yang di Alami

4) Penyusunan metode pembelajaran berupa ceramah dan tanya jawab.

5) Persiapan sumber belajar dan bahan ajar.

6) Penyusunan alat evaluasi pembelajaran atau lembar kerja peserta didik (LKS)

\section{b. Pelaksanaan}

1) Kegiatan awal (10 menit)

a) Guru mengajak peserta didik berdoa, mengisi daftar kelas, menulis hari dan tanggal di papan tulis dan mempersiapkan materi ajar.

b) Guru memperingatkan peserta didik cara duduk yang baik ketika menulis, membaca dan meluruskan barisan meja dan kursi mereka

c) Guru memberikan motivasi belajar kepada para peserta didik melalui "tepuk semangat" dan menyanyikan lagu "Pada Hari Minggu"

d) Guru memperlihatkan contoh peristiwa penting yang pernah dialami diikuti tanya jawab untuk mengetahui kemampuan awal peserta didik tentang apa yang akan dipelajari

e) Guru menyampaikan tujuan pembelajaran setelah pembelajaran peserta didik dapat menyebutkan peristiwa yang pernah di alami 
f) Guru menyampaikan topik yang akan dipelajari yaitu "Peristiwa Penting yang di Alami"

g) Guru mengaitkan tofik dengan menyampaikan manfaat konsep tersebut dalam kehidupan sehari-hari

2) Kegiatan inti (40 menit)

a) Guru menyebutkan beberapa Peristiwa Penting yang di Alami

b) Guru menjelaskan kejadian yang telah terjadi peristiwa ada yang penting ada yang biasa saja ada yang masih kita ingat ada pula yang sudah kita lupa dengan perlihat gambar beberapa peristiwa penting

c) Guru meminta peserta didik memperhatikan gambar Peristiwa Penting yang di Alami

d) Peserta didik diminta menyebutkan dan Peristiwa penting yang alami di rumah dan di lingkungan sekitar atau sekolah dengan media yang mereka bawa

e) Guru meminta beberapa peserta didik untuk maju kedepan menyebutkan peristiwa penting yang alami di rumah dan di lingkungan sekitar atau sekolah dengan media yang mereka bawa

f) Guru memberikan penguatan kepada peserta didik

g) Guru memberikan kesempatan peserta didik untuk bertanya

3). Kegiatan Akhir (20 menit)
a) Guru bersama peserta didik menyimpulkan pembelajaran
b) Guru memberikan tugas berupa LKS terkait materi yang baru saja dipelajari.
c) Peserta didik mengerjakan tugas yang diberikan guru.
d) Guru memberian PR / tugas
e) Menutup pelajaran

\section{c. Pengamatan}


Peneliti melakukan pengamatan terhadap aktivitas peserta didik dalam mengikuti perbaikan pembelajaran dengan metode demonstrasi. Hasil pengamatan ternyata ada perubahan yang sangat berbeda karena peserta didik menjadi aktif, antusias, dan mengerti dengan jelas materi yang dipelajari. Hal itu berpengaruh dari hasil belajar yang meningkat dari Siklus I (nilai rerata 67,58) ke Siklus II (nilai rerata 88,55). Hal ini dikarena

a. Guru sudah menggunakan media pembelajaran yang sesuai secara maksimal sehingga tidak terciptanya suasana pembelajaran yang kondusif, dan menyenangkan bagi peserta didik

b. Guru sudah menggunakan metode pembelajaran dan teknik pembelajaran yang bervariasi dan efektif

c. Guru sudah memberikan motivasi pada saat pembelajaran berlangsung sehingga peserta didik tidak tertarik pada pelajaran IPS

d. Guru sudah mengadakan reward dan umpan balik secara langsung selama pembelajaran, sehingga peserta didik tidak aktif

\section{d. Refleksi}

Dalam melakukan refleksi perbaikan pembelajaran, penulis dan teman sejawat mencatat beberapa hal yang sangat berpengaruh pada penerapan metode demonstrasi melalui media gambar yaitu:

1) Dengan menggunakan metode demonstrasi, peserta didik mendapatkan suasan baru, sehingga dapat menghindari kebosanan dalam proses pembelajaran.

2) Dengan metode demonstrasi, dapat membiasakan peserta didik untuk berkomunikasi aktif dalam bertukar fikiran dengan teman.

3) metode demonstrasi, peserta didik diajarkan untuk mandiri, dan memiliki rasa setia kawan yang tinggi.

4) Dengan metode demonstrasi pada perbaikan pembelajaran pada siklus II ini hasil nila rerata peserta didik sebesar 88,55 dan 28 
daris 31 peserta didik (93.5\%)) yang mendapat nilai di atas KKM. Sedangkan Hasil pengamatan didapat data peserta didik yang dapat menjawab pertanyaan guru dengan benar sebanyak 28dari 31 peserta didik atau sebesar $(90.32 \%)$

5) Dengan metode demonstrasi mendapatkan keuntungan, menambah pengalaman dan kepercayaan diri, peserta didik Pada akhirnya kualitas dan hasil belajar semakin membaik, sehingga tidak dilanjutkan dengan siklus berikutnya.

\section{Teknik Analisis Data}

Data yang telah dikumpulkan pada setiap kegiatan observasi dari pelaksanaan siklus penelitian dianalisissecara deskriptif dengan menggunakan teknik presentase untuk melihat kecenderungan yang terjadi dalam kegiatan pembelajaran mata pelajaran IPS.

Dalam pelaksanaan penelitian ini membutuhkan dua siklus perbaikan untuk mata pelajaran matematika. Pada proses perbaikan pembelajaran yang peneliti lakukan adalah melalui tiga tahapan, yaitu diantaranya adalah : perencanaan, pelaksanaan, pengamatan dan refleksi.

Langkah-langkah dalam teknik analisis data yang dilakukan adalah sebagai berikut:

1. Melaksanakan kegiatan pembelajaran, yang terdiri dari kegiatan prasiklus, siklus 1, dan siklus 2 .

2. Mengumpulkan dan menganalisis nilai evaluasi pembelajaran dari tiap siklus.

3. Mendiskripsikan dan membandingkan nilai evaluasi dari tiap siklus.

4. Menentukan tingkat keberhasilan dari hasil evaluasi yang ditempuh dalam proses pembelajaran.

5. Tes, yang digunakan untuk mendapatkan data tentang hasil belajar peserta didik. 
6. Observasi, yang digunakan untuk mengumpulkan data tentang perkembangan keaktifan peserta didik dalam proses kegiatan belajar mengajar dengan menggunakan metode demonstrasi.

\section{HASIL PENELITIAN DAN PEMBAHASAN}

\section{A. Deskripsi Hasil Perbaikan Pembelajaran}

Dalam Pelaksanaan Penelitian Tindakan Kelas, peneliti dibantu oleh rekan sejawat untuk mengobservasi dan memberikan masukan terhadap pelaksanaan pembelajaran yang akan dilakukan. Selanjutnya dalam proses pembelajaran, peneliti berdiskusi dengan rekan sejawat untuk menemukan kekurangan dalam proses pembelajaran yang telah dilakukan. Selain itu, peneliti melakukan refleksi atas pembelajaran yang dilakukan untuk memutuskan perbaikan pembelajaran selanjutnya.

Instrumen yang dilakukan oleh peneliti sebagai berikut :

1. Instrumen pengamatan untuk mengetahui hasil belajar peserta didik.

2. Instrumen pengamatan peserta didik yang dapat menjawab pertanyaan guru dengan benar.

3. Lembar evaluasi per siklus.

Hasil refleksi pada proses pembelajaran mata pelajaran IPA yang telah dilaksanakan oleh peneliti yaitu sebagai berikut :

1. Nilai rerata pembelajaran IPA di bawah KKM yang telah ditetapkan 70 .

2. Peserta didik kurang termotivasi dalam pembelajaran.

3. Materi yang disampaikan masih sulit dimengerti oleh peserta didik.

4. Peserta didik menjadi pasif karena media dan metode yang kurang tepat.

5. Tanggung jawab peserta didik terhadap tugas masih rendah

Dalam proses belajar mengajar pada prasiklus diperoleh beberapa permasalahan, yaitu.

1. Guru belum menggunakan media pembelajaran yang sesuai secara maksimal sehingga tidak terciptanya suasana pembelajaran yang kondusif, dan menyenangkan bagi peserta didik 
2. Guru belum menggunakan metode pembelajaran dan teknik pembelajaran yang bervariasi dan efektif

3. Guru kurang memberikan motivasi pada saat pembelajaran berlangsung sehingga peserta didik tidak tertarik pada pelajaran IPA

4. Guru jarang mengadakan reward dan umpan balik secara langsung selama pembelajaran, sehingga peserta didik tidak aktif.

Berdasarkan hasil pembelajaran maka peneliti menemukan data tiap siklus. Data-data yang ditemukan adalah sebagai berikut :

\section{Prasiklus}

Pada prasiklus diperoleh data nilai hasil evaluasi dengan jumlah nilai 2318 , nilai rerata 61 , nilai tertinggi 85 , nilai terendah 25 . Hal ini dapat diperinci sebagai berikut 18 peserta didik (47\%) mendapat nilai di bawah KKM, 12 peserta didik (32\%) mendapat nilai sama dengan KKM dan hanya 8 peserta didik (21\%) yang mendapat nilai di atas KKM sehingga yang mencapai KKM 20 peserta didik (53\%). Sedangkan hasil pengamatan peserta didik yang dapat menjawab pertanyaan guru dengan benar sebanyak 14 dari 38 peserta didik atau sebesar $(36,84 \%)$ dan sejumlah 24 dari 38 peserta didik yang belum dapat menjawab pertanyaan guru dengan benar atau sebesar $(63,16 \%)$.

\section{Siklus I}

Pada siklus I peneliti menambah metode pembelajaran menjadi metode ceramah, diskusi, tanya jawab dan pemberian tugas. Hasil evaluasi peserta didik meningkat dengan hasil nilai rerata 69 dari KKM 70 dengan jumlah nilai 2625, nilai tertinggi 90 dan nilai terendah 50. Selanjutnya dapat diperinci sebagai berikut 10 peserta didik (26\%) mendapat nilai di bawah KKM, 21 peserta didik (55\%) mendapat nilai sama dengan KKM dan hanya 7 peserta didik (19\%) yang mendapat nilai di atas KKM. Sehingga yang mencapai ketuntasan sebesar (74\%). Sedangkan hasil pengamatan peserta didik yang dapat menjawab pertanyaan guru dengan benar sebanyak 21 dari 38 peserta didik atau sebesar $(55,26 \%)$ dan 
sejumlah 17 dari 38 peserta didik yang belum dapat menjawab pertanyaan guru dengan benar atau sebesar $(44,74 \%)$.

\section{Siklus II}

Berdasarkan hasil obserpasi peneliti pada siklus 2 didapat data hasil nilai rerata 81. Data tersebut dapat dirinci sebagai berikut jumlah nilai 3072, nilai tertinggi 100, dan nilai terendah 50. Dengan Hasil tersebut maka terdapat 4 peserta didik (11\%) mendapat nilai di bawah KKM, 13 peserta didik (34\%) mendapat nilai sama dengan KKM, 21 peserta didik (55\%) yang mendapat nilai di atas KKM. Sehingga peserta yang tuntas mencapai KKM (89 \%) Sedangkan Hasil pengamatan didapat data peserta didik yang dapat menjawab pertanyaan guru dengan benar sebanyak 27 dari 38 peserta didik atau sebesar $(71,05 \%)$ dan sejumlah 11 dari 38 peserta didik yang belum dapat menjawab pertanyaan guru dengan benar atau sebesar $(28,95 \%)$.

Dari hasil evaluasi pembelajaran siklus I, mata pelajaran IPA belum mencapai hasil yang diharapkan, sehingga peneliti melakukan perbaikan pembelajaran pada siklus II. Hasil dari perbaikan pembelajaran pada siklus II mencapai ketuntasan 34 peserta didik dari 38 peserta didik atau sebesar 89\% dengan nilai rerata 81 dan hasil pengamatan sebesar $71,05 \%$. Berikut ini adalah data hasil rekapitulasi nilai dan hasil pengamatan peserta didik pada mata pelajaran IPA dalam bentuk tabel.

Berdasarkan uraian di atas maka penulis menyajikan rekapitulasi nilai rerata tiap siklus serta grafik nilai rerata, nilai ketuntasan dan hasil pengamatan. 
Tabel 1

Rekapitulasi Nilai Rerata Setiap Siklus

\begin{tabular}{|c|c|c|c|c|c|}
\hline No & Nama Peserta didik & $\mathbf{L} / \mathbf{P}$ & Prasiklus & Siklus I & Siklus II \\
\hline 1 & Adam Saputra & $\mathrm{L}$ & 70 & 70 & 85 \\
\hline 2 & Aditya Tri Pamungkas & $\mathrm{L}$ & 70 & 70 & 60 \\
\hline 3 & Angga Setiyadi & $\mathrm{L}$ & 40 & 60 & 50 \\
\hline 4 & Anggun Rahmania & $\mathrm{P}$ & 75 & 80 & 95 \\
\hline 5 & Asri Fajriyani Alya Putri & $\mathrm{P}$ & 28 & 60 & 62 \\
\hline 6 & Asyifatu Zahra & $\mathrm{P}$ & 70 & 70 & 100 \\
\hline 7 & Bagas Adytiya & $\mathrm{L}$ & 65 & 70 & 75 \\
\hline 8 & Benaya Sabrina Putri & $\mathrm{P}$ & 85 & 90 & 100 \\
\hline 9 & Canisya Pradiani & $\mathrm{P}$ & 40 & 70 & 70 \\
\hline 10 & Duta Sandi Pala & $\mathrm{L}$ & 70 & 70 & 70 \\
\hline 11 & Erlisya Jaharanis & $\mathrm{P}$ & 50 & 70 & 90 \\
\hline 12 & Esyal Setiawan & $\mathrm{L}$ & 70 & 65 & 90 \\
\hline 13 & Faisal Fahriz & $\mathrm{L}$ & 75 & 70 & 70 \\
\hline 14 & Fajrin Haerun Nisa & $\mathrm{P}$ & 70 & 70 & 95 \\
\hline 15 & Fitri Alfiyani & $P$ & 25 & 80 & 95 \\
\hline 16 & Fitria Rahma Juwita & $\mathrm{P}$ & 50 & 70 & 95 \\
\hline 17 & Gilang Aji Saputro & $\mathrm{L}$ & 70 & 80 & 95 \\
\hline 18 & Jihan Nur Azizah Sukmawati & $\mathrm{P}$ & 70 & 70 & 95 \\
\hline 19 & Merty Rana Saputri & $\mathrm{P}$ & 70 & 70 & 70 \\
\hline 20 & Mu'ammar Febrian & $\mathrm{L}$ & 50 & 60 & 90 \\
\hline 21 & Muhammad Lutfiansyah & $\mathrm{L}$ & 75 & 80 & 70 \\
\hline 22 & Muhammad Nabil & $\mathrm{L}$ & 50 & 70 & 80 \\
\hline 23 & Muhammad Ridho Alfiansyah & $\mathrm{L}$ & 50 & 50 & 85 \\
\hline 24 & Muhammad Faqih Hidayat & $\mathrm{L}$ & 50 & 70 & 70 \\
\hline 25 & Muhammad Hafiz Alrasyid & $\mathrm{L}$ & 40 & 50 & 75 \\
\hline 26 & Mutia Rahmah & $\mathrm{P}$ & 80 & 70 & 100 \\
\hline 27 & Nadia Nursefiana & $\mathrm{P}$ & 30 & 60 & 75 \\
\hline 28 & Nadira Vara Salsabila & $\mathrm{P}$ & 80 & 70 & 100 \\
\hline 29 & Naufal Muhammad Fakhri & $\mathrm{L}$ & 65 & 60 & 70 \\
\hline 30 & Noval Alfarizi Ramadhan & $\mathrm{L}$ & 60 & 60 & 80 \\
\hline 31 & Rafli Tri Alamsyah & $\mathrm{L}$ & 50 & 70 & 70 \\
\hline 32 & Reza Alamsyah & $\mathrm{L}$ & 70 & 80 & 70 \\
\hline 33 & Riefani Anndinia & $\mathrm{P}$ & 80 & 70 & 100 \\
\hline 34 & Rika Ayu Prasetianingsih & $P$ & 70 & 80 & 60 \\
\hline 35 & Rizky Nofrianti Putri & $\mathrm{L}$ & 40 & 70 & 70 \\
\hline 36 & Selfi Oktaviani Putri & $\mathrm{P}$ & 65 & 60 & 90 \\
\hline 37 & Siti Nur Amalia & $\mathrm{P}$ & 80 & 70 & 70 \\
\hline 38 & Yayan Wikhana & $\mathrm{P}$ & 70 & 70 & 85 \\
\hline \multicolumn{3}{|c|}{ Jumlah } & 2318 & 2625 & 3072 \\
\hline \multicolumn{3}{|c|}{ Rerata } & 61 & 69 & 81 \\
\hline \multicolumn{3}{|c|}{ Nilai Tertinggi } & 85 & 90 & 100 \\
\hline \multicolumn{3}{|c|}{ Nilai Terendah } & 25 & 50 & 50 \\
\hline \multicolumn{3}{|c|}{ KKM } & 70 & 70 & 70 \\
\hline
\end{tabular}


Tabel 2

Data Rekapitulisasi Pengamatan Hasil Belajar Pra Siklus, Siklus 1, Siklus 2

\begin{tabular}{|c|c|c|c|c|c|c|c|c|}
\hline \multirow{2}{*}{ No } & \multirow{2}{*}{ NAMA } & & \multicolumn{2}{|c|}{ Prasiklus } & \multicolumn{2}{|c|}{ Siklus 1} & \multicolumn{2}{|c|}{ Siklus 2} \\
\hline & & & $\mathrm{M}$ & TM & $\mathrm{M}$ & $\mathrm{TM}$ & $\mathrm{M}$ & TM \\
\hline 1 & Adam Saputra & $\mathrm{L}$ & $\sqrt{ }$ & & $\sqrt{ }$ & & $\sqrt{ }$ & \\
\hline 2 & Aditya Tri Pamungkas & $\mathrm{L}$ & & $\sqrt{ }$ & & $\sqrt{ }$ & & $\sqrt{ }$ \\
\hline 3 & Angga Setiyadi & $\mathrm{L}$ & $\sqrt{ }$ & & $\sqrt{ }$ & & $\sqrt{ }$ & \\
\hline 4 & Anggun Rahmania & $\mathrm{P}$ & $\sqrt{ }$ & & $\sqrt{ }$ & & $\sqrt{ }$ & \\
\hline 5 & Asri Fajriyani Alya Putri & $\mathrm{P}$ & $\sqrt{ }$ & & $\sqrt{ }$ & & $\sqrt{ }$ & \\
\hline 6 & Asyifatu Zahra & $\mathrm{P}$ & & $\sqrt{ }$ & $\sqrt{ }$ & & & $\sqrt{ }$ \\
\hline 7 & Bagas Adytiya & $\mathrm{L}$ & & $\sqrt{ }$ & & $\sqrt{ }$ & $\sqrt{ }$ & \\
\hline 8 & Benaya Sabrina Putri & $\mathrm{P}$ & $\sqrt{ }$ & & $\sqrt{ }$ & & $\sqrt{ }$ & \\
\hline 9 & Canisya Pradiani & $\mathrm{P}$ & & $\sqrt{ }$ & & $\sqrt{ }$ & $\sqrt{ }$ & \\
\hline 10 & Duta Sandi Pala & $\mathrm{L}$ & & $\sqrt{ }$ & $\sqrt{ }$ & & $\sqrt{ }$ & \\
\hline 11 & Erlisya Jaharanis & $\mathrm{P}$ & $\sqrt{ }$ & & $\sqrt{ }$ & & $\sqrt{ }$ & \\
\hline 12 & Esyal Setiawan & $\mathrm{L}$ & & $\sqrt{ }$ & & $\sqrt{ }$ & $\sqrt{ }$ & \\
\hline 13 & Faisal Fahriz & $\mathrm{L}$ & & $\sqrt{ }$ & & $\sqrt{ }$ & & $\sqrt{ }$ \\
\hline 14 & Fajrin Haerun Nisa & $\mathrm{P}$ & $\sqrt{ }$ & & $\sqrt{ }$ & & $\sqrt{ }$ & \\
\hline 15 & Fitri Alfiyani & $\mathrm{P}$ & & $\sqrt{ }$ & & $\sqrt{ }$ & & $\sqrt{ }$ \\
\hline 16 & Fitria Rahma Juwita & $\mathrm{P}$ & & $\sqrt{ }$ & & $\sqrt{ }$ & $\sqrt{ }$ & \\
\hline 17 & Gilang Aji Saputro & $\mathrm{L}$ & & $\sqrt{ }$ & $\sqrt{ }$ & & & $\sqrt{ }$ \\
\hline 18 & Jihan Nur Azizah Sukmawati & $\mathrm{P}$ & $\sqrt{ }$ & & $\sqrt{ }$ & & $\sqrt{ }$ & \\
\hline 19 & Merty Rana Saputri & $\mathrm{P}$ & & $\sqrt{ }$ & & $\sqrt{ }$ & $\sqrt{ }$ & \\
\hline 20 & Mu'ammar Febrian & $\mathrm{L}$ & & $\sqrt{ }$ & & $\sqrt{ }$ & & $\sqrt{ }$ \\
\hline 21 & Muhammad Lutfiansyah & $\mathrm{L}$ & $\sqrt{ }$ & & $\sqrt{ }$ & & $\sqrt{ }$ & \\
\hline 22 & Muhammad Nabil & $\mathrm{L}$ & $\sqrt{ }$ & & $\sqrt{ }$ & & $\sqrt{ }$ & \\
\hline 23 & Muhammad Ridho A & $\mathrm{L}$ & & $\sqrt{ }$ & & $\sqrt{ }$ & $\sqrt{ }$ & \\
\hline 24 & Muhammad Faqih Hidayat & $\mathrm{L}$ & & $\sqrt{ }$ & $\sqrt{ }$ & & $\sqrt{ }$ & \\
\hline 25 & Muhammad Hafiz Alrasyid & $\mathrm{L}$ & & $\sqrt{ }$ & & $\sqrt{ }$ & $\sqrt{ }$ & \\
\hline 26 & Mutia Rahmah & $\mathrm{P}$ & & $\sqrt{ }$ & & $\sqrt{ }$ & & $\sqrt{ }$ \\
\hline 27 & Nadia Nursefiana & $\mathrm{P}$ & & $\sqrt{ }$ & & $\sqrt{ }$ & & $\sqrt{ }$ \\
\hline 28 & Nadira Vara Salsabila & $\mathrm{P}$ & & $\sqrt{ }$ & $\sqrt{ }$ & & $\sqrt{ }$ & \\
\hline 29 & Naufal Muhammad Fakhri & $\mathrm{L}$ & $\sqrt{ }$ & & $\sqrt{ }$ & & $\sqrt{ }$ & \\
\hline 30 & Noval Alfarizi Ramadhan & $\mathrm{L}$ & $\sqrt{ }$ & & $\sqrt{ }$ & & $\sqrt{ }$ & \\
\hline 31 & Rafli Tri Alamsyah & $\mathrm{L}$ & & $\sqrt{ }$ & & $\sqrt{ }$ & $\sqrt{ }$ & \\
\hline 32 & Reza Alamsyah & $\mathrm{L}$ & & $\sqrt{ }$ & & $\sqrt{ }$ & $\sqrt{ }$ & \\
\hline 33 & Riefani Anndinia & $\mathrm{P}$ & & $\sqrt{ }$ & $\sqrt{ }$ & & & $\sqrt{ }$ \\
\hline 34 & Rika Ayu Prasetianingsih & $\mathrm{P}$ & & $\sqrt{ }$ & & $\sqrt{ }$ & & $\sqrt{ }$ \\
\hline 35 & Rizky Nofrianti Putri & $\mathrm{L}$ & $\sqrt{ }$ & & $\sqrt{ }$ & & $\sqrt{ }$ & \\
\hline 36 & Selfi Oktaviani Putri & $\mathrm{P}$ & & $\sqrt{ }$ & & $\sqrt{ }$ & & $\sqrt{ }$ \\
\hline 37 & Siti Nur Amalia & $\mathrm{P}$ & & $\sqrt{ }$ & $\sqrt{ }$ & & $\sqrt{ }$ & \\
\hline 38 & Yayan Wikhana & $\mathrm{P}$ & $\sqrt{ }$ & & $\sqrt{ }$ & & $\sqrt{ }$ & \\
\hline \multicolumn{3}{|c|}{ Jumlah } & 14 & 24 & 21 & 17 & 27 & 11 \\
\hline \multicolumn{3}{|c|}{ Prosentase } & 36,84 & 63,16 & 55,26 & 44,74 & 71,05 & 28,95 \\
\hline
\end{tabular}




\section{B. Pembahasan Hasil Penelitian Perbaikan Pembelajaran}

Pada prasiklus diperoleh data nilai hasil evaluasi dengan nilai rerata 61 . Hal ini dapat diperinci sebagai berikut 18 peserta didik (47\%) mendapat nilai di bawah KKM, 12 peserta didik (32\%) mendapat nilai sama dengan KKM dan hanya 8 peserta didik (21\%) yang mendapat nilai di atas KKM. Melalui pengamatan, peserta didik yang dapat menjawab pertanyaan guru 36,84\% dan yang belum dapat menjawab sebesar 63,16\%. Berdasarkan tabel 3 di bawah, hasil pengamatan peserta didik yang dapat menjawab pertanyaan guru dengan benar sebanyak 14 dari 38 peserta didik atau sebesar $(36,84 \%)$ dan sejumlah 24 dari 38 peserta didik yang belum dapat menjawab pertanyaan guru dengan benar atau sebesar $(63,16 \%)$.

Pada pembelajaran prasiklus ini nilai rerata pembelajaran IPA di bawah KKM, sehingga pretasi belajar masih rendah. Selanjutnya peserta didik kurang termotivasi dalam pembelajaran, peserta didik menjadi pasif dan tanggung jawab peserta didik terhadap tugas masih rendah. Penyebab faktor tersebut disebababkan karena (1) Guru belum menggunakan media pembelajaran yang sesuai secara maksimal sehingga tidak terciptanya suasana pembelajaran yang kondusif, dan menyenangkan bagi peserta didik. (2) Guru belum menggunakan metode pembelajaran dan teknik pembelajaran yang bervariasi dan efektif (3) Guru kurang memberikan motivasi pada saat pembelajaran berlangsung sehingga peserta didik tidak tertarik pada pelajaran IPA. (4) Guru jarang mengadakan reward dan umpan balik secara langsung selama pembelajaran, sehingga peserta didik tidak aktif.

Berdasarkan hasil observasi, refleksi dan diskusi dengan supervisor 1 (teman sejawat), Kondisi tersebut akhirnya membuat peneliti meneruskan untuk melakukan penelitian ke siklus 1. Pada siklus I peneliti menambah metode pembelajaran menjadi metode ceramah, diskusi, tanya jawab dan pemberian tugas. Hasil evaluasi peserta didik meningkat dengan hasil nilai rerata 69 dari KKM 70 dengan jumlah nilai 2625, nilai tertinggi 90 dan nilai terendah 50. Selanjutnya dapat diperinci sebagai berikut 10 peserta didik 
(26\%) mendapat nilai di bawah KKM, 21 peserta didik (55\%) mendapat nilai sama dengan KKM dan hanya 7 peserta didik (19\%) yang mendapat nilai di atas KKM. Sedangkan hasil pengamatan peserta didik yang dapat menjawab pertanyaan guru dengan benar sebanyak 21 dari 38 peserta didik atau sebesar $(55,26 \%)$ dan sejumlah 17 dari 38 peserta didik yang belum dapat menjawab pertanyaan guru dengan benar atau sebesar $(44,74 \%)$.

Penyebab rendah prestasi belajar peserta didik adalah sebagai berikut.

1. Guru belum menggunakan media pembelajaran yang sesuai secara maksimal sehingga tidak terciptanya suasana pembelajaran yang kondusif, dan menyenangkan bagi peserta didik

2. Guru belum menggunakan metode pembelajaran dan teknik pembelajaran yang bervariasi dan efektif

3. Guru kurang memberikan motivasi pada saat pembelajaran berlangsung sehingga peserta didik tidak tertarik pada pelajaran IPA

4. Guru jarang mengadakan reward dan umpan balik secara langsung selama pembelajaran, sehingga peserta didik tidak aktif.

Pada siklus I, ini walau peneliti menambahkan metode tanya jawab. Hasil evaluasi peserta didik mengalami peningkatan dengan hasil nilai rerata 69 dengan hasil ketuntasan 47\%, hasil pengamatan yang dapat menjawab pertanyaan guru sebesar 55,26\%. Namun demikian, pencapaian nilai peserta didik masih di bawah KKM. Sehingga peneliti melanjutkan perbaikan pembelajaran sampai siklus II.

Pada perbaikan pembelajaran siklus 2 maka penulis merefleksi harus melakukan berbagai tindakan agar prestasi belajar peserta dapat ditingkat, peserta didik termotivasi dalam pembelajaran, materi yang disampaikan dimengerti oleh peserta didik, dan Tanggung jawab peserta didik terhadap tugas agar tinggi

Untuk mengatasi permasalah tersebut maka peneliti melakukan sebagai berikut : 
1. Menggunakan media pembelajaran yang sesuai secara maksimal sehingga tidak terciptanya suasana pembelajaran yang kondusif, dan menyenangkan bagi peserta didik

2. Menggunakan metode pembelajaran dan teknik pembelajaran yang bervariasi dan efektif

3. Memberikan motivasi pada saat pembelajaran berlangsung sehingga peserta didik tidak tertarik pada pelajaran IPA

4. Mengadakan reward dan umpan balik secara langsung selama pembelajaran, sehingga peserta didik tidak aktif.

Perbaikan pembelajaran pada siklus II ini penulis menggunakan metode demonstrasi. Berdasarkan hasil obserpasi didapat data hasil nila rerata peserta didik sebesar 81. Data tersebut dapat dirinci sebagai berikut jumalah nilai 3072 nilai tertinggi 100 nilai terendah 50. Dengan rincian 4 peserta didik (11\%) mendapat nilai di bawah KKM, 13 peserta didik (34\%) mendapat nilai sama dengan KKM dan 21 peserta didik (55\%) yang mendapat nilai di atas KKM.

Sedangkan Hasil pengamatan didapat data peserta didik yang dapat menjawab pertanyaan guru dengan benar sebanyak 27 dari 38 peserta didik atau sebesar $(71,05 \%)$ dan sejumlah 11 dari 38 peserta didik yang belum dapat menjawab pertanyaan guru dengan benar atau sebesar $(28,95 \%)$.

Dengan demikian penerapan metode demonstrasi telah memberikan pengaruh yang sangat baik pada hasil belajar peserta didik. Hal ini dapat :

1. Meningkatkan prestasi belajar peserta didik,

2. Peserta didik termotivasi dalam pembelajaran,

3. Materi yang disampaikan dimengerti peserta didik,

4. Tanggung jawab peserta didik terhadap tugas tinggi,

5. Membantu peserta didik untuk terlibat aktif di dalam kelas dan

6. Peserta didik mempunyai pengalaman baru dalam proses belajar.

\section{KESIMPULAN DAN SARAN TINDAK LANJUT}

\section{A. Kesimpulan}


Berdasarkan hasil Penelitian Tindakan Kelas (PTK) melalui aktivitas perbaikan pembelajaran yang telah dilaksanakan mulai dari prasiklus, siklus I sampai dengan siklus II pada mata pelajaran IPA, penulis dapat menarik kesimpulan sebagai berikut :

1. Pada prasiklus diperoleh data nilai hasil evaluasi dengan nilai rerata 61 , terdapat 20 atau (53\%) peserta didik mendapat nilai diatas KKM, Sedangkan hasil pengamatan peserta didik yang dapat menjawab pertanyaan guru dengan benar sebanyak 14 peserta didik (36,84\%). Pada siklus I didapat hasil nilai rerata 69, terdapat 28 (74\%) peserta didik tuntas dengan hasil pengamatan peserta didik yang dapat menjawab pertanyaan guru dengan benar sebanyak 21 (55,26\%). Berdasarkan hasil obserpasi peneliti pada siklus 2 didapat data hasil nila rerata 81 terdapat 34 peserta didik atau (89 \%) peserta didik tuntas sedangkan hasil pengamatan didapat peserta didik yang dapat menjawab pertanyaan guru dengan benar sebanyak $27(71,05 \%)$ dan sejumlah $11(28,95 \%)$ peserta didik yang belum dapat menjawab pertanyaan guru dengan benar.

2. Dengan demikian penerapan metode demonstrasi telah memberikan pengaruh yang sangat baik dengan termotivasi peserta didik untuk belajar, materi yang disampaikan guru dimengerti, peserta didik memiliki tanggung jawab terhadap tugasnya, dan peserta didik terlibat aktif di dalam kelas Hal berdampak meningkatnya prestasi belajar peserta didik. yang belajar peserta didik mata pelajaran IPA di kelas VI SDN Limo 2 Depok.

\section{B. Saran Tindak Lanjut}

Berdasarkan pada kesimpulan diatas ada beberapa hal yang sebaiknya dilakukan guru dalam upaya meningkatkan hasil belajar peserta didik.

1. Motivasi yang kuat sangat dibutuhkan oleh seorang peserta didik sebelum melakukan pembelajaran.

2. Suasana belajar yang aktif di dalam kelas akan memotivasi peserta didik dalam belajar. 
3. Penggunaan metode demonstrasi dapat membantu peserta didik untuk lebih cepat memahami konsep materi pelajaran. Dalam hal ini metode demonstrasi dapat menjadi alternatif yang digunakan guru dalam mengajarkan pembelajaran IPA.

4. Memberikan kesempatan kepada peserta didik untuk lebih aktif di kelas, mengeluarkan pendapat untuk menumbuhkan rasa percaya diri serta keberanian anak dalam menjawab pertanyaan

\section{Referensi}

Anitah, W, Sri dkk (2009:1.3). Strategi Pembelajaran di SD. Tanggerang Selatan : Universitas Terbuka.

Azhar, Arsyad, (2004). Media Pembelajaran. Jakarta: PT Raja Grafindo Persada. Arsyad, Arsyad, \& Sulfemi, Wahyu Bagja. (2014). Minat Siswa Tentang Keadministrasian dengan Hasil Belajar Administrasi Perkantoran. Edutecno 9 (2), 40-50.

Arsyad, Arsyad dan Sulfemi, Wahyu Bagja. (2018) Metode Role Playing Berbantu Media Audio Visual Pendidikan dalam Meningkatkan Belajar IPS. Jurnal Pendidikan Ilmu Pengetahuan Sosial Indonesia. 3 (2). $41-46$.

Arikunto, Suharsimi (2012). Penelitian Tindakan Kelas, Jakarta: Bumi Aksara

Asrori, Muhammad (2009), Penelitian Tindakan Kelas, Bandung: CV Wacana Prima.

Departemen Pendidikan Nasional (2008). Kamus Besar Bahasa Indonesia Pusat Bahasa. Jakarta : Gramedia Pustaka Utama.

Gagne, R. M., Briggs, L.J.,Wager, W.W. (1992). Principles Of Instructional Design. New york: Harcourt Brance Jovanovich College Publisher.

Sapriati, Amalia.(2012).Pembelajaran IPA di SD. Jakarta: Universitas Terbuka.

Sagala, Syaiful. (2008). Konsep dan Makna Pembelajaran. Jakarta: Alfabeta

Slameto. (2003), Belajar dan Fakta yang mempengaruhinya. Jakarta: Rineka Cipta

Syah, Muhibbin. (2004), Psikologi Pendidikan dengan Pendekatan Baru. Bandung Remaja Rosdakarya. 
Sulfemi, Wahyu Bagja. (2013). Pengaruh Persepsi Siswa atas Kemampuan Pedagogik Guru dan Motivasi Belajar Siswa Terhadap Prestasi Belajar Ilmu Pengetahuan Sosial Siswa (Survei di SMK Swasta Kabupaten Bogor). Edutecno. 7 (2), 17-26.

Sulfemi, Wahyu Bagja. (2014). Pengaruh Motivasi dan Lingkungan Sekolah Terhadap Prestasi Belajar Sejarah Di SMA Negeri Leuwilang Kabupaten Bogor. Fascho : Kajian Pendidikan dan Sosial Kemasyarakatan 9 (2), 42-52

Sulfemi, Wahyu Bagja. (2015). Pengaruh Metode Pembelajaran Kontekstual dan Penggunaan Media Video Pendidikan Terhadap Hasil Belajar IPS. Edutecno 13 (2), 1-10

Sulfemi, Wahyu Bagja. (2016). Hubungan Persepsi Peserta Didik Tentang Kompetensi Guru Mata Pelajaran Sejarah dengan Hasil Belajar Mata Pelajaran Sejarah di Kelas X SMA Negeri 1 Pamijahan Kabupaten Bogor. Fascho, 5 (2), 52-70

Sulfemi, Wahyu Bagja. (2016). Hubungan antara Persepsi Guru pada Kepemimpian Kepala Sekolah dan Motivasi Guru dengan Kinerja guru dalam Proses Pembelajaran di SMA Negeri 1 Ciomas. Fascho : Kajian Pendidikan dan Sosial Kemasyarakatan, 5 (1), 36-55

Sulfemi, Wahyu Bagja. (2016). Perundang-Undangan Pendidikan. Bogor : Program Studi Administrasi Pendidikan STKIP Muhammadiyah Bogor.

Sulfemi, Wahyu Bagja dan Lestari, Ayu Hopilatul. (2017). Korelasi Kompetensi Pedagogik Guru dengan Prestasi Belajar Mata Pelajaran IPS Di SMP Muhammadiyah Pamijahan Kabupaten Bogor. Edutecno. 16 (1), 116

Sulfemi, Wahyu Bagja dan Abdul Qodir. (2017). Hubungan Kurikulum 2013 Dengan Motivasi Belajar Peserta Didik Di SMK Pelita Ciampea. Edutecno 17 (2), 1-8.

Sulfemi, Wahyu Bagja. (2017). Analisis Pengaruh Motivasi Dan Disiplin Terhadap Kinerja Guru (Studi Kasus di SMA Negeri 1 Pamijahan Kabupaten Kabupaten Bogor). Prosiding Seminar Nasonal STKIP Muhammadiyah Bogor. 1 (1), 342-357

Supardi, (2012). Penelitian Tindakan Kelas, Jakarta: Bumi Akasra

Tim Penyusun Naskah PLPG PGSD FIP UNJ, (2011). Modul Pendidikan dan Latihan Profesi Guru Sekolah Dasar. Jakarta: Universitas Negeri Jakarta

Wardhani, IGAK, (2014). Penelitian Tindakan Kelas. Tangerang Selatan: Universitas Terbuka. 
